\section{Entre o clássico e o contemporâneo: uma (re) leitura dos fundamentos históricos do direito constitucional comparado}

\author{
BETWEEN THE CLASSIC AND THE CONTEMPORARY: \\ A (RE) LECTURE OF HISTORICAL FOUNDATIONS OF \\ THE CONSTITUTIONAL LAW COMPARED \\ * Gabriel Lima Marques
}

Resumo: O presente trabalho tem por escopo desempenhar um resgate sucinto da origem e do desenvolvimento do direito constitucional comparado, dando-se uma atenção para aquilo que o caracteriza modernamente. Em tal âmbito, cuida-se de demonstrar que esta não se trata de uma disciplina surgida recentemente, embora por conta de diversos fatores o interesse pela mesma tenha ao longo do tempo variado. À vista disso, o que se propõe apresentar é que nos dias correntes, a utilização de referências estrangeiras de natureza constitucional pelas supremas cortes, muito em conta provocada pelos recentes processos de globalização e de proliferação de constituições escritas, foi responsável tanto por fazer ressurgir o interesse acadêmico pelo direito constitucional comparado, quanto por renovar os questionamentos a ele inerentes.

Palavras-Chave: Direito constitucional; Direito Comparado; Suprema corte.

Abstract: The present paper has the purpose to play a brief rescue of the origin and development of comparative constitutional law, giving attention to what characterizes it in modern times. In such a context, it cares to demonstrate that it is not a discipline that emerged recently, although on account of several factors, interest in it has varied over time. In view of this, what intends to present is that, at this recent days, the use of foreign constitutional references by supreme courts, very mindful caused by recent processes of globalization and proliferation of written constitution, was responsible for both resurrecting academic interest in comparative constitutional law, as to renew the questions inherent to it.

Keywords: Constitutional law; Comparative law; Supreme court. 
on the topic, contrasting the understanding of the authors: "Neoconstitutionalism and the constitutionalization of law. The late triumph of constitutional law in Brazil" by Luis Roberto Barroso and "Neoconstitutionalism and legal moralism" by Dimitri Dimoulis. At the end, it is concluded that, despite the undeniable changes and significant social and political contributions provided by the 1988 Constitution, the phenomenon widely referred to the term "neoconstitutionalism" claims in questionable premises of historical, theoretical and philosophical view, being an overly imprecise expression to explain the contemporary legal reality.

Keywords: Constitution; theory of law; morality, hermeneutics. 


\section{INTRODUÇÃO}

A expressão direito constitucional comparado, de acordo com Monica Claes (2012, p. 230), possui quatro acepções possíveis, conforme o escopo que se pretenda atingir. Na primeira delas, a pesquisa comparatista é utilizada para melhor compreender um ou mais sistemas jurídicos. Neste sentido, percebendo como cada sistema lida com as adversidades que lhes são subjacentes, os desafios se tornam conhecidos e, como consequência, abre-se a oportunidade de se pensar soluções mais adequadas a eles. Já por outro lado, em um segundo sentido concebível, o cotejamento pode ter ainda como objetivo, permitir um ganho de compreensão mais profundo da própria Constituição. Quer dizer, com base no material contrastado recolhido, figura-se realizável o desenvolvimento de uma capacidade de reflexão crítica sobre o próprio texto político.

Dando prosseguimento, identifica também a professora da Universidade de Maastricht (CLAES, 2012, p. 231), que o uso do arcabouço comparativo, pode ter por propósito estabelecer quais são as melhores práticas, ou mesmo, quais são, normativamente falando, as melhores soluções para uma dada situação. Tal tipo de pesquisa, revela-se como sendo a mais relevante, tanto para processos de elaboração de novas constituições, quanto, e mais atualmente, para a interpretação destas. Por fim, mas, diga-se de passagem, não menos importante, vale assinalar de igual modo, que a jurista holandesa (CLAES, 2012, p. 232) chama a atenção ainda para o fato de que o constitucionalismo comparado pode figurar de igual modo como sendo um relevante instrumento para o desenvolvimento de um direito transnacional. Isso por que, pensando principalmente na realidade do continente europeu, quando o tribunal de direitos humanos, com o intento de conferir uma solução a um caso concreto, necessita interpretar a convenção ${ }^{1}$, ele procura na tradição constitucional dos países que compõe a União Europeia, o que lá se entende, por exemplo, por cláusulas abertas como liberdade ou Estado de Direito, para alcançar uma conclusão. Neste sentido, em um verdadeiro processo de fertilização cruzada (crossfertilization $)^{2}$, o tribunal transnacional se vale do material comparado, produzido

\footnotetext{
A menção aqui é à Convenção para a proteção dos Direitos do Homem e das liberdades fundamentais, adotada pelo conselho da Europa em 1950, e cuja observância é tarefa atribuída ao Tribunal Europeu de Direitos Humanos.

2 A fertilização cruzada, em síntese, pode ser definida como a interação entre sistemas legais. Afinal, como sintetiza Esin Örücü (1996, p. 432), “[...] todos os sistemas jurídicos contêm ideias, conceitos, estruturas e regras nascidos em outros solos legais que se movem e se entrecruzam. Todos os sistemas são misturados, e mesmo quando o Estado-Nação é considerado como a única fonte do Direito, os sistemas tem invariavelmente suas origens misturadas, isto é, os elementos que se combinam para formar um sistema são de diferentes fontes legais[...]”.
} 
nacionalmente, mas, por sua vez, também influencia esses mesmos países com sua jurisprudência, até que com isso, o direito europeu assuma para si valores aceitos e compartilhados comunitariamente.

Inserido nesta compreensão, o presente artigo tem como meta, justamente, apresentar um vínculo entre estes significados e a própria evolução do direito constitucional comparado. Quer dizer, trata-se de observar como os sentidos elencados acima revelam, em verdade, o desenvolvimento do modo como o aparato comparatista, no âmbito público, se deu ao longo da história do pensamento jurídico ocidental. Assim, discutindo problemas que podem ser chamados de constitucionais, ${ }^{3}$ rastos deste raciocínio podem ser encontrados já nos escritos de Aristóteles. Posteriormente, pode-se citar ainda, o uso da comparação nos trabalhos dos grandes pensadores políticos do século XVIII, destacando-se em relevo, nesse caso, a figura de Montesquieu.

Com o surgimento, porém, de fenômenos tais como a globalização, a proliferação de novos processos constituintes e a consolidação do papel das Supremas Cortes, passou-se a operar uma verdadeira transformação, e a atenção volta-se, ainda que sem excluir as demais, às duas últimas perspectivas apontas acima nos estudos de Monica Claes. Exatamente por isso, mostra-se oportuno acentuar a existência, tanto de um viés clássico, quanto de um contemporâneo neste campo. E os meandros históricos de como essa transformação ocorreu, dando-se enfoque ao uso de referências estrangeiras pelas cortes constitucionais, é o que se propõe aqui estudar.

Parar cumprir tal intento, contudo, é preciso deixar claro existir uma verdadeira dificuldade de sistematizar informações neste sentido. Isso por que, conforme já asseverava Walter Hug (1931, p. 1028-1029) no começo dos anos 30 do século passado, declaração esta, aliás, que malgrado a distância temporal continua corrente, "[...] nunca houve uma tentativa abrangente de traçar este histórico, nem muito menos se encontra qualquer pesquisa nesta direção [...]". Deste modo, sem qualquer pretensão de esgotar o assunto, entretanto, sem também desmerecer o potencial didático e elucidador desta tarefa, principalmente no que toca a demonstração da ruptura que se operou entre as vertentes clássica e atual do

\footnotetext{
3 Diz-se assim, pois atualmente é possível classificar algumas das preocupações desses autores como sendo de ordem constitucional. Todavia, muito embora tratassem de aspectos neste sentido, seus objetivos estavam centrados na resolução de outros problemas, tais como a vida boa, ou a perpetuação do Estado.
} 
constitucionalismo comparado, o que se pretende a seguir é expor, de maneira sutil e seletiva, a linhagem histórica dessa disciplina. Deve-se esclarecer, antes disso, porém, que a periodização que se propõe abaixo, inevitavelmente padece de um modo ou de outro, de um certo grau de subjetividade, afinal, como muito bem pontuam Enrique Gacto Fernández, José Marín e Juan Alejandre (1997, p. 11), “[...] a divisão da História em períodos, ainda que indispensável, tem um valor secundário, sendo sempre imprecisa e flutuante, e até certo ponto, arbitrária [...]”.

\section{ARISTÓTELES E A GÊNESE DO DIREITO CONSTITUCIONAL COMPARADO}

Convencionalmente, em razão da organização de um trabalho cuja publicação, porém, se deu apenas em um momento posterior, sob o título de A Política, Aristóteles é assinalado como sendo o pioneiro ${ }^{4}$ nos estudos do constitucionalismo comparado (DIXON \& GINSBURG, 2012, p. 01). ${ }^{5}$ Afinal, com enfoque especial no objetivo de teorizar aquilo que para ele poder-seia considerar enquanto um design ótimo de constituição, ${ }^{6}$ e baseando-se para tanto, em um conceito substantivo, ${ }^{7}$ o filósofo reuniu e analisou mais de uma centena de leis fundamentais de Estados e Confederações da Antiguidade, ${ }^{8}$ e com base nesse material, produziu uma série de generalizações fundamentais, tais como: “[...] o conceito de Constituição enquanto forma de organização jurídica do político, a ideia de uma Constituição como momento fundante da organização política, além do elemento precursor do que atualmente se conhece como controle de constitucionalidade [...]" (LOIS, 2001, p. 14).

\footnotetext{
${ }^{4}$ De acordo com Roberto Scarciglia (2011, p. 29), outros pensadores gregos também desempenharam este tipo de tarefa, sendo, porém, pouco conhecidos. É o caso de Dicearco de Messina (350290 A.C), Timeo de Tauromenio (356-260 A.C) e Teofrasto de Ereso (372-287 A.C).

5 Uma objeção, porém, deve ser feita. Afinal, como muito bem apontam Lucio Pergoraro e Angello Rinella (2000, p. 29), o direito comparado tal qual o conhecemos hoje, é produto da ciência jurídica moderna. Contudo, "[...] é inegável que já na antiguidade seja possível descobrir indícios da comparação jurídica, através do interesse que se tinha pelo direito estrangeiro, e na curiosidade científica que induz a mirar além do próprio direito [...]".

6 Aristóteles, neste ponto, conforme assevera Daniel Devereux (2011, p. 111) “[...] concorda com Platão de que a finalidade de uma comunidade política é a felicidade geral de seus membros, e de que o fator decisivo para se atingir tal intento é o design da Constituição [...]".

7 A Constituição ou Politéia, significa para Aristóteles a estrutura peculiar de um determinado Estado (MCILWAIN, 2007, p. 26).

${ }^{8}$ Diz-se normalmente que foram 158. E dentre estas, as mais famosas, certamente são a de Atenas, a de Esparta (Lacedemônia), a de Creta e a de Cartago.
} 
De igual modo, foi também a partir deste aparato comparatista, que o estagirita acabou por proceder a sua famosa classificação das formas de governo (ROSENFELD \& SAJÓ, 2012, p. 03). ${ }^{9}$ Assim, diferenciando e agrupando as constituições a que havia investigado, pelo número daqueles que detinham o poder, o filósofo concluiu que se o governo estivesse nas mãos de poucos, então, estar-se-ia diante de uma lei fundamental oligárquica ou aristocrática. Se, por outro lado, a tomada de decisão estivesse vinculada apenas a uma pessoa, então ter-se-ia uma constituição monárquica ou tirânica. Por fim, caso o poder se mostrasse aberto a muitos, à lex máxima, desta forma, poder-se-ia tanto ser democrática, quanto republicana (DEVEREUX, 2011, p. 113).

Diante disto, vê-se, portanto, que foi atuando de forma despretensiosa que Aristóteles acabou por transformar seu estudo em um verdadeiro bastião de investigações no campo que ora se estuda. Isso por que, como observado acima, a confrontação para ele possuía apenas natureza instrumental, quer dizer, sua proposta era a de se utilizar do raciocínio comparativo de matriz empírica para perseguir o objetivo a que se lhe havia proposto. ${ }^{10}$ É o que, aliás, pode ser corroborado se tomarmos em consideração as próprias palavras do filósofo em sua obra. De acordo com o estagirita (1985, p. 35), esse tipo de pesquisa revelouse necessária por que as constituições existentes até então, pouco satisfaziam a sua intenção de reflexionar um sistema ideal. Desta forma, somente à confrontação entre as estruturas, deficiências e imperfeições destas, teria o condão de auxiliá-lo na tarefa de formar um padrão ideal de Politéia (BITTAR, 2003, p. 1229).

Ocorre, porém, que apesar do empenho pioneiro do filósofo grego, no sentido de inaugurar a via da reflexão comparatista no âmbito constitucional, migrando-se o olhar para fora de seus escritos percebe-se nitidamente uma descontinuidade entre as suas investigações e os trabalhos elaborados na sequência. Exatamente por isso, levará tempo até que a comparação constitucional seja finalmente redescoberta.

\footnotetext{
${ }^{9}$ Conforme alude David Hahm (2009, p. 186) “[...] Um dos maiores projetos de Aristóteles na Política foi definir e avaliar as constituições e explicar as mudanças de uma forma de governo para outra, principalmente entre Oligarquia e Democracia. Esta foi a mudança mais comum nas cidadesestado gregas à época, tendo inclusive ocorrido em Atenas. [...]"

${ }^{10}$ De acordo com Günter Frankenberg (2012, p. 175), esta afirmativa é verificável a partir de três vertentes. Primeiro, por que Aristóteles cotejava para construir filosoficamente o que para ele seria o modelo ideal de constituição aplicável a uma pólis. Segundo, por que o pensador grego analisava contrapostamente os aspectos sociológicos das leis básicas, incluindo o fator não-legal como contexto. E por último, por que o estagirita concentrou esforços na engenharia constitucional, para encontrar leis fundamentais adaptadas paradigmaticamente a determinadas nações ou a ambientes supranacionais.
} 


\section{MONTESQUIEU E A ETAPA OITOCENTISTA: PRELÚDIOS DO MODERNO DIREITO CONSTITUCIONAL COMPARADO}

Conquanto seja possível hoje detectar indícios de comparação já no período renascentista, caso por exemplo, do trabalho intitulado De Laudibus legum Angliae ${ }^{11}$ da autoria do inglês John Fortescue, ou mesmo, haja a viabilidade fática de apontarmos prenúncios deste tipo de pesquisa ainda no século XVII, reclamando o interesse neste caso, estudiosos como Georg Struve ${ }^{12}$ e Gottfried Leibiniz. ${ }^{13}$ No plano constitucional, é somente a partir do limiar do século das luzes, e com os esforços de Montesquieu, que a moderna comparação se estabelecerá (ZWEIGERT \& KÖTZ, 2002, p. 55).

Isso por que, eis aqui um diferencial que, aliás, o torna autêntico, o pensador francês se utilizará do material estrangeiro não mais enquanto mera ilustração, mas sim como um importante suporte a reforma sugerida por ele próprio (HUG, 1931, p. 1050). Neste sentido, partindo do pressuposto de "[...] que todo homem investido em autoridade é levado a dela abusar, indo até onde encontra limites [...]" (MONTESQUIEU, 1996, p. 166), e além disso, é claro, levando também em consideração a estrutura política da Inglaterra, país no qual viveu por alguns anos, o filósofo de Bordeaux, deduz na sua famigerada obra, $O$ Espírito das Leis, que a liberdade, ${ }^{14}$ preocupação tão em voga numa Europa ainda presa aos grilhões do absolutismo, não seria por si só uma virtude a se esperar das instituições, mas sim um produto das condições de exercício da autoridade. Deste modo, o problema não estaria no acolhimento puro e simples de uma ou outra forma de governo, se república (aristocrática ou democrática) ou monarquia, mas na gestão destas, que caso fosse deficiente, resultaria de forma inevitável no regime despótico (MARTINEZ, 2012, p. 550). ${ }^{15}$ Em sendo assim, apenas se adotando, à exemplo

\footnotetext{
${ }^{11}$ No trabalho em questão, Fortescue, um magistrado inglês do século XV, comparou as leis da Inglaterra e da França de sua época, limitando-se a concluir, porém, que o direito inglês era superior.

${ }^{12}$ Jurista alemão que se notabilizou por comparar o direito privado alemão ao direito privado romano na obra Syntagma jurisprudentiae, secundum ordinem Pandectarum concinnatum.

${ }^{13}$ Seu projeto de um Theatrum Legale (1667) compreendia uma representação comparativa das leis de todos os povos, países e épocas (ALMEIDA \& CARVALHO, 2013, p. 07), todavia, por ter modificado seus interesses não o levou adiante.

${ }^{14} \mathrm{O}$ que para Montesquieu (1996, p. 166), vale a menção, consistia em poder fazer o que se deve querer, e em não ser forçado a fazer o que não se tem o direito de querer.

${ }^{15}$ Para Montesquieu, o governo despótico era aquele no qual um homem governa sozinho de acordo com suas vontades e caprichos. O déspota, então, não possui regras que o limite. Ele é livre para matar, se ele assim o quiser. Em síntese, o governo não é contrabalançeado, e não possui o seu ingrediente mais importante, a moderação (JENNINGS, 2011, p. 332).
} 
dos ingleses, um sistema de freios e contrapesos jurídicos, no qual o poder, subidivido em pessoas ou corpos distintos, fosse o óbice do próprio poder, seria possível a instituição de um governo moderado. ${ }^{16}$

Este governo, segundo o autor, somente se realizaria no mundo dos fatos, caso a Constituição, assim como no caso britânico, indicasse neste sentido, do contrário, não (BISCARETTI DI RUFFIA, 1962, p. 130). Exatamente por isso, é comumente afirmado que o governo tido como constitucional, remonta a confrontação entre experiências políticas distintas (SARASOLA, 2009, p. 09). Afinal, muito embora esta não fosse a intenção de Montesquieu, já que escrevia a partir de sua condição, a nobreza, suas ideias alguns anos depois de tê-las escrito, acabaram sendo tomadas como alicerce tanto pelos arquitetos liberais da Revolução Americana quanto pelos do levante francês. Sua influência nestes episódios, aliás, foi de tal monta, que o segundo Congresso Continental da Filadélfia ${ }^{17}$ chegou a intitulá-lo de "o imortal", e o artigo 16 da Declaração Francesa dos Direitos do Homem e do Cidadão de 1789, por sua vez, achou por bem estabelecer que qualquer sociedade que não assegurasse a separação de poderes, não poderia se considerar constitucional.

Neste âmbito, e por representar uma alternativa ao já saturado Ancien Régime, o movimento constitucionalista pouco a pouco foi se propagando ao redor do globo. Fosse qual fosse a forma política que o Estado assumisse, fosse qual fosse o elemento preponderante do governo, e até mesmo, fosse qual fosse o sistema de divisão territorial e político do Estado, sob a míriade da experiência franco-norte-americana, ${ }^{18}$ exigia-se que as bases políticas de qualquer regime ficassem consagradas numa Carta (COSTA, 1915, pp. 2728). Afinal, era tanto o que determinava uma sempiterna necessidade de

\footnotetext{
${ }^{16}$ Neste tipo de governo, que não importa o regime por meio do qual se traduz, o poder é sempre devidamente controlado, e o povo, em contrapartida encontra-se seguro (KLOSKO, 2013, p. 244).

${ }^{17}$ Congresso que se reuniu a partir de 1775 , e que contou com a participação de delegados das antigas treze colônias. Motivados pela intransigência do governo inglês em atender suas demandas, os representantes no ano de 1776, acabaram por firmar a Declaração de Independência dos Estados Unidos da América.

${ }^{18}$ De acordo com Rosenfeld e Sajó (2012, pp. 03-04) “[...] O direito constitucional comparado tornou-se particularmente relevante a partir do resultado das revoluções nos Estados Unidos e na França. Os Founding Fathers e os revolucionários franceses tiveram que inventar uma nova organização para o Estado, e para isso eles apenas podiam contar com uma limitada extensão das estruturas pré-existentes. A evidência empírica, então, através da comparação, funcionou tanto como fonte de inspiração quanto de legitimação. Nos Federalists Papers, referências a experiências estrangeiras foram feitas para justificar objetivos. Na França, a tradução da coleção da constituição norte-americana tornou-se uma das fontes intelectuais mais importantes para o pensamento político reformista e revolucionário, e comparações com os arranjos ingleses e norte-americanos eram comuns nos debates da Assembleia Nacional Constituinte [...]”.
} 
segurança jurídica, quanto, e da mesma forma, os ideais de cunho racionalista, ${ }^{19}$ que agora confiavam à razão humana, a fundação e a organização das sociedades.

Diante deste quadro, assitiu-se ao longo de todo o século XIX, a um verdadeiro processo de transferência de tecnologia jurídico-política. Isso por que, neste período, a Constituição escrita tornou-se principalmente entre os Estados da Europa ocidental, e entre os recém-fundados países da América Latina, no produto estrangeiro que mais se desejava importar (DIXON \& GINSBURG, 2012, p. 02). Daí é que se seguem, por exemplo, sem qualquer pretensão exaustiva, a Lei Fundamental da Espanha de 1812, a da Noruega de 1814, a do Grão-Ducado de Baden de 1818, a da Colômbia de 1821, a de Portugal de 1822, a do Brasil de 1824, a da Argentina de 1826, as da Venezuela e do Uruguai de 1830, e tantas outras. Em cada caso, em virtude de pela primeira vez haver a facilidade de acesso aos textos, os autores destas novas Cartas Políticas tanto tomavam emprestado modelos estrangeiros tidos como ideais, quanto os adaptavam às condições locais (TAKII, 2006). Como resultado, a comparação neste campo, à época, tornou-se extremamente popular (MARCOS, 2003, pp. 314-316). ${ }^{20}$

Ocorre que, paralelo a essa prática, porém, no período que compreende boa parte da primeira métade da etapa oitocentista, a Europa esteve profundamente marcada por um movimento de introversão nacional. ${ }^{21}$ Neste contexto, como era de se esperar, privilegiavasse uma visão ptolomaica do Direito, e como consequência direta, cada ordenamento acreditava piamente ser o centro do mundo jurídico. Assim sendo, à exceção de alguns parcos esforços fragmentados, incertos e ocasionais, ${ }^{22}$ iniciados e sustentados por um

\footnotetext{
${ }^{19}$ Segundo as ideias racionalistas, que tiveram grande influência durante o século XVIII, a razão possui a capacidade de definir para cada sociedade qual o regime político que a ela melhor se adéqua, bem como quais os meios necessários para mantê-lo racionalmente.

${ }^{20}$ Conforme salienta Adolfo Posada (1906, p. 210) "[...] A expansão do regime constitucional pelo mundo é em grande parte resultado do procedimento comparativo na construção das doutrinas políticas e na redação dos textos constitucionais [...]".

${ }^{21}$ Isso por que "[...] depois da personalização romântica da nação e, especificamente, da racionalização da organização e consolidação dos Estados, como quadros exclusivos e instrumentos essenciais da vida nacional, o conjunto dos fenômenos sócio-humanos foi repensado de modo aberto e seletivo, em função, essencialmente, desta nova realidade. Neste contexto, a atividade política, social, econômica, cultural e, até mesmo, científica dos povos e dos homens, torna-se estritamente nacional. O mesmo, em maior grau, acontece com o Direito positivo e a ciência jurídica. A unidade jurídica europeia, tão frágil, é substituída progressivamente pela diversidade resultante da existência paralela de uma pluralidade de Direitos positivos nacionais. A própria ciência jurídica gradualmente se deixa fechar nas mônades dos relativos ordenamentos [...]" (CONSTANTINESCO, 1998, p. 4647).

${ }^{22}$ Um deles, por exemplo, e que vale ser citado, é o famoso Bureau de Legislation Comparée, que funcionou entre os anos de 1801 e 1804, e que se limitou apenas a traduzir o Código Geral para os Estados Prussianos de 1794 para o idioma francês (BALLIN, 1953, p. 267).
} 
mero espírito de curiosidade científica, pouco ou quase nenhum interesse teórico, acabou por caminhar na direção de estudos comparativos durante este ciclo (CONSTANTINESCO, 1998, p. 47). ${ }^{23}$ Afinal, como os juristas, embebidos pelo positivismo, ${ }^{24}$ estavam concentrados demais no estudo e na interpretação dos códigos de seus países, ${ }^{25}$ considerava-se o direito comparado como carente de valor (HUG, 1931, p. 1053).

Foi preciso, contudo, aguardar o desenvolver do século XIX para que este panorama se modificasse. Isso por que, o desenvolvimento do comércio internacional e a facilidade das relações humanas daí decorrentes, ${ }^{26}$ possibilitou a composição de "[...] um clima de curiosidade, de atenção e de simpatia pelas experiências estrangeiras [...]" (ANCEL, 1980, p. 21). Nesta senda, a preocupação científica em torno do direito comparado, e os contornos de uma disciplina acadêmica começam a se delinear. ${ }^{27}$ Assim, em 1829, sob os esforços de Karl Salomo Zachariä e Joseph Mittermaier é fundado na Alemanha, o primeiro periódico de que se tem notícia, dedicado ao direito comparado, o Kritische Zeitschrift für Rechtswissenschaft und

${ }^{23}$ Conforme identifica Constantinesco (1998, p. 130), os progressos até então haviam sido muito modestos, "[...] na maior parte dos casos, contentava-se com as traduções dos códigos e de leis estrangeiras, mas estas constituem somente instrumentos preliminares e muito insuficientes para fazer conhecer o 'Direito estrangeiro'. Além disso, a percepção dos modelos estrangeiros se originava quase que exclusivamente em fatores práticos. Os juristas não se preocupavam em inserir estas observações em um processo sistemático, nem de fundar o Direito comparado como uma ciência autônoma $[\ldots]$ ".

${ }^{24}$ Como se sabe, durante este período, encontrava-se em seu ápice, a famosa Escola da Exegese. A mesma, segundo Norberto Bobbio (1995, p. 83), deve seu nome à técnica adotada pelos seus primeiros expoentes no estudo e exposição do Código de Napoleão de 1804, o que consistia "[...] em assumir pelo tratamento científico o mesmo sistema de distribuição da matéria seguido pelo legislador, e sem mais, em reduzir tal tratamento a um comentário, artigo por artigo, do próprio Código [...]".

${ }^{25}$ Como apontam muito bem Rosenfeld e Sajó (2012, p. 04) “[...] Este foi o tempo dos exegetas, cuja tarefa não era fornecer soluções criativas, mas guiar autoritariamente e com segurança os advogados e administradores através de um labirinto de um cada vez maior corpo de leis. Isto é, a prevalência do sucesso do positivismo legal desvalorizou o interesse por todas as outras fontes do Direito que não fosse o texto, onde se exprimia a norma legal positiva. Neste âmbito, a ciência legal se tornou autorreferente e orientada à sistematização, e assim, seus objetivos metodológicos não abriam muito espaço para a comparação [...]".

${ }^{26}$ Peculiaridades advindas do processo de industrialização, que desenvolveu novas sociedades marcadas pelo compartilhamento de traços e interesses comuns ou, ao revés, de rivalidades, levando-as a se observarem mutuamente (ANCEL, 1980, p. 21).

${ }^{27}$ Impende-nos salientar que este desenvolvimento, porém, se dará em um primeiro momento no plano da legislação. Isso fica nítido, sobretudo em países como a França, onde as grandes codificações levaram a um fetichismo da lei, e onde era dominante a ilusão de que todo o Direito estaria contido nos textos legislativos. Eis assim o porquê de até o Congresso de Paris, no ano de 1900, falar-se quase que exclusivamente em legislação comparada e não em Direito Comparado (CONSTANTINESCO, 1998, p. 135). 
Gesetzgebung des Auslandes, "Periódico crítico para a ciência jurídica e a legislação estrangeira" (ZWEIGERT \& KÖTZ, 2002, p. 60). ${ }^{28}$ Já em 1831, têm-se no Collège de France, a primeira cátedra no mundo de História da Legislação Comparada, sendo ocupada por Eugène Lerminier. Por último, em 1869, ${ }^{29}$ ainda em terras francesas, é de igual modo frequentemente lembrado como um dos símbolos do surgimento do direito comparado, e de seu reconhecimento pleno como ramo da ciência jurídica, a criação, baixo a liderança de Édouard de Laboulaye, da Sociedade de Legislação Comparada (ZWEIGERT \& KÖTZ, 2002, p. 63). ${ }^{30}$

Frente a este profícuo cenário, conforme identifica Marc Ancel (1980, p. 23), surge "[...] uma concepção da utilidade do direito comparado, qual seja, a de informar de maneira precisa e rigorosa, sobre as instituições estrangeiras e procurar, nas experiências dos outros países, os meios técnicos de suprir as lacunas e as imperfeições do direito nacional [...]". Exatamente por isso, passase a se verificar, cada vez mais, uma interpenetração geográfica das orientações e das ideias concernentes ao Direito comparado, razão pela qual, a pesquisa neste campo, "[...] tanto na Europa quanto na América, passa não mais a consistir nos esforços de alguns poucos homens isolados, mas torna-se um reconhecido instrumento de desenvolvimento do Direito [...]" (GUTTERIDGE, 1949, p. 16). ${ }^{31}$ Como resultado direto, a disciplina gradualmente vai sendo incorporada aos programas universitários, afinal, todo o trabalho empreendido até então resultaria insuficiente se não fosse complementado pelo pensamento científico. Assim, próximo ao fim do século, o Direito privado comparado já era objeto de estudo, por exemplo, em Londres, Turim, Zurich, Nápoles, Génova, Lovaina e Budapeste. O Direito público, por sua vez, em Lovaina, Nápoles, Gante e Genebra. E no caso específico do Direito constitucional comparado, este desde 1895 também vinha sendo disponibilizado na França, todavia, apenas no âmbito do Doutorado (POSADA, 1906, p. 213-214).

\footnotetext{
${ }^{28}$ Revista que através de seus 28 volumes, editados ao longo de quase três décadas, possibilitou o conhecimento quase que completo da atividade científico-legal de vários países.

${ }^{29}$ No mesmo ano na Inglaterra, vale a menção, Henry Summer Maine se convertia no primeiro professor de Jurisprudência histórica e comparativa em Oxford.

${ }^{30}$ Sociedade cujos estatutos definem o seu objeto como o estudo das leis dos diferentes países e a pesquisa dos meios práticos de aprimorar os diversos ramos da legislação. Em conjunto com a sua publicação, a Revue Internationale de Droit Comparé, existe até os dias de hoje.

${ }^{31}$ Como escrevia Adhémar Smein (1900, p. 374) "[...] a preocupação quanto ao Direito Comparado ingressou nos hábitos dos legisladores modernos. Não há, pode-se afirmar, nenhum projeto de lei importante que seja apresentado em qualquer parlamento da Europa, sem que seja precedido de uma exposição de motivos, com uma larga lista de Direito comparado [...]”.
} 
Ora, como neste ínterim [...] se assiste a um autêntico florescimento de ideias, de concepções e de iniciativas relativas ao Direito comparado [...] (CONSTANTINESCO, 1998, p. 135) as tentativas de lhe assegurar um campo de atuação próprio passam a se combinar com as concepções mais diversas. Falava-se, no mesmo espaço de tempo, “[...] em legislação comparada, em Direito comparado, em jurisprudência comparada, em jurisprudência etnológica, em História comparativa do Direito, em Direito comum legislativo, em História comparativa das instituições, em Direito nacional comparado com o estrangeiro, em política comparada, em política jurídica fundada na comparação [...]" (POSADA, 1906, p. 232), e tantos outros. Por assim ser, sentia-se a necessidade de se propiciar uma ocasião na qual houvesse a possibilidade de se discutir e pensar alguns dos problemas fundamentais ${ }^{32}$ que à época se ventilavam. ${ }^{33}$ Deste modo, alicerçada neste intuito, e inspirada tanto pelo chamado Clima de Haia, quanto pela atmosfera da Belle Époque, a Société de Législation Comparée, convoca para o ano de 1900, na cidade de Paris, um Congresso de Direito Comparado.

No encontro, cuja direção coube a Raymond Saleilles, estiveram reunidas as principais personalidades do comparativismo mundial de então. ${ }^{34}$ Dentre eles, emergiu como ideia fundamental e norteadora dos debates, a tese de que "[...] a comparação dos direitos, cientificamente organizada, deveria trazer à lume, sob a diversidade das soluções nacionais e a divergência das legislações existentes, um fundo comum [...]" (ANCEL, 1980 , p. 29), que se constituiria pelos princípios gerais de Direito, reconhecidos pelos "países civilizados". Tais princípios, como muito bem pontua Marc Ancel (1980, p. 30), não seriam descobertos somente através de uma lógica jurídica sobre a qual os representantes de distintos sistemas pudessem concordar in abstracto, nem muito menos seriam produto de um

\footnotetext{
${ }^{32}$ Certamente, um dos problemas de maior relevância que dominaram as discussões no Congresso, girou em torno do fato de se estar diante de um Método ou de uma Ciência. Todavia, muito embora esta tenha sido uma preocupação constante nos primórdios do nascimento do Direito Comparado, conforme aponta Leontin Constantinesco (1998, p. 233), tais disputas, por se perderem cada vez mais em controvérsias abstratas ou em discussões estéreis, com o passar do tempo acabaram perdendo a importância.

${ }^{33}$ De acordo com Saleilles (1909, p. 165), no que se refere a este campo, tudo restava ainda a ser descoberto, afinal, o que havia sido feito até então, nada mais era do que trabalhos de Direito estrangeiro sem comparação, ou estudos etnológicos, sociológicos e históricos.

${ }^{34}$ Dentre eles, vale especial menção ao brasileiro Ataulpho Napoles de Paiva, posteriormente Ministro do Supremo Tribunal Federal e testemunha ocular do evento. Para mais informações, não se podem olvidar suas valiosas contribuições no texto de sua autoria, "O Brasil no Congresso Internacional de Direito Comparado de Paris", publicado no ano de 1900.
} 
direito natural, anterior ou exterior e, em todo caso, superior ao direito dos povos. Na verdade, "[...] a comparação metódica das legislações e das instituições jurídicas revelaria, sob formulações quiçá distintas, que certas normas de direito positivo se encontram em um e outro sistemas e, por assim ser, se constituem em regras de direito comum legislativo [...]". Assim, seria papel do direito comparado, justamente revelar essas regras comuns, que daí em diante funcionariam como uma fonte subsidiária em relação à interpretação judicial e às reformas legislativas (CONSTANTINESCO, 1998, p. 218).

Todavia, para que esta pretensão universalista fosse alcançada, os comparatistas tinham plena consciência de que deveriam levar em consideração apenas os países que tivessem tido praticamente o mesmo desenvolvimento político, social, econômico e moral (ANCEL, 1980, p. 30). Deste modo, buscando fundamento em uma nem tão distante tradição romano-germânica (ANCEL, 1980, p. 32), os interesses intelectuais a partir da Conferência, acabaram quase que na sua inteireza, por convergir, no sentido de se tomar em conta tanto como objeto de estudo a Europa continental, ${ }^{35}$ quanto por buscar a harmonização da política jurídica internacional apenas e tão somente no campo privado (DIXON \& GINSBURG, 2011, p. 02). Entrementes, eis o motivo pelo qual o Direito Constitucional Comparado foi tão explorado no campo prático, especificamente como instrumento informativo para a elaboração de Textos Políticos, porém tão pouco no plano teórico. Diante disto, e excepcionandose apenas alguns poucos trabalhos, ${ }^{36}$ será somente a partir do fim do primeiro grande conflito de ordem mundial que tal realidade passará a ensair sinais de mudança.

\footnotetext{
${ }^{35}$ É o que igualmente vão afirmar ZWEIGERT \& KÖTZ. De acordo com os autores (2002, p. 65), "[...] A finalidade deste Congresso para o direito comparado, até onde podemos discernir, devido a grande quantidade de especialistas que interviram, consistia em descobrir um droit commun législatif, ou um acerco comum de soluções e, assim, estabelecer uma relação mais estreita entre os diferentes sistemas jurídicos do mundo. O Congresso de Paris não só definiu as matérias de direito comparado, tal como se formulavam até então, também infundiu à suas atividades, um otimismo e uma fé ilimitada na unidade mundial, em que pese ter imposto limites a seus alcances, pois o suposto de que somente se podiam comparar coisas comparáveis, se traduziu em uma concentração desmedida no direito codificado e nos temas jurídicos da Europa continental [...]".

${ }^{36}$ Merecem aqui destaque, sem dúvidas, o trabalho da autoria de Adolfo Posada, "Derecho Político Comparado" e o de John Burguess "Political Science and Comparative Constitutional Law".
} 


\section{O MUNDO PÓS-GUERRAS: CONTORNOS DA ECLOSÃO DA DOUTRINA CLÁSSICA DO DIREITO CONSTITUCIONAL COMPARADO}

Transposto os umbrais do século XX e finda a primeira guerra de escala global, os interesses em torno da pesquisa comparatista foram gradativamente modificando sua ênfase. Da discussão de questões tais como "[...] quais são os propósitos da utilidade do direito comparado, e qual é o lugar que este ocupa dentro da ciência do Direito em geral, obsessões do Congresso de Paris de 1900, caminhou-se de modo paulatino a estudos em torno de problemas práticos [...]" (ZWEIGERT \& KÖTZ, 2002, p. 66). ${ }^{37}$ De um modo geral, isso se deu em grande medida, em razão de "[...] os estudiosos terem se dado conta de que havia tantos materiais jurídicos por estudar e tantos novos conceitos por conhecer, que representaria uma limitante para o direito comparado definir, de antemão, os objetivos ou o lugar que deveria ocupar dentro do sistema [...]" (Op. Cit. p. $67)$.

Neste contexto, os comparativistas começam a se conscientizar, primeiramente, da existência, da importância e da extensão do sistema da common law, e um vasto movimento passa a se delinear na direção de conhecêlo. ${ }^{38}$ Com isso, conforme esclarece Marc Ancel (1980, p. 35):

“[...] descobre-se um mundo novo, onde os métodos, os conceitos, a análise dos problemas concretos são radicalmente diferentes, ou até mesmo inexistentes, no sentido continental da palavra, onde a divisão do direito público e do direito privado, as noções de direito comercial ou de direito administrativo não são admitidas tradicionalmente, onde se deve, ao contrário, se adaptar à divisão entre a common law e a equity, onde a Real Property constitui um mundo hermético, e onde lhes é preciso assimilar o sentido de termos intraduzíveis de forma direta para a linguagem continental, como a consideration, o trust, a specific performance, o estoppel, e o trespass [...]".

\footnotetext{
${ }^{37}$ Tipo de pesquisa também conhecido pela expressão francesa recherche concrète (ANCEL, 1968, p. 27).

${ }^{38}$ De acordo com Zweigert e Kötz (2002, pp. 67-68) “[...] Esta extensão dos estudos comparativos ao common law, junto com os sistemas romano e eurocontinental romperam para sempre com os limites impostos pelo Congresso de Paris de 1900. Após o necessário abandono da ideia, segundo a qual, somente os sistemas com estruturas comparáveis proporcionavam uma base comparativa, demonstrou-se que a comparação de sistemas totalmente diferentes entre si poderiam ser úteis e proveitosos, bem como que a verdadeira base da comparação era tanto a similitude de função quanto a necessidade social, cuja satisfação poderia depender de conceitos extremamente distintos. Tal fato proporcionou ao direito comparado um ponto de partida imemorável do ponto de vista metodológico, bem como, em grande medida, o fez uma importante ferramenta para a investigação mesmo dos sistemas legais mais distintos [...]".
} 
À luz destas complexas problemáticas, e com o intuito de as verem solvidas, os pesquisadores dão início a um processo de organização de institutos, que com o suceder do tempo foram ganhando popularidade e, exatamente por isso, se multiplicando entre os países. Assim, na França, por exemplo, é criado por Edouard Lambert, em 1920, o Institut de Droit comparé.$^{39}$ Em Roma, na Itália, em 1927 e sob a direção de Salvatore Galgano, o Istituto di studi legislativi. ${ }^{40} \mathrm{E}$ nos Estados Unidos, na direção inversa ${ }^{41}$ a Parker School of Foreign and Comparative Law em $1919,{ }^{42}$ e a American Foreign Law Association, ${ }^{43}$ em 1925 (SCARCIGLIA, 2011, pp. 52-54).

Ocorre que tais iniciativas tinham por preocupação central a investigação na seara privada, sendo pouco, ou quase nenhum enfoque dado ao direito constitucional. Contudo, isso não quer dizer que não tenhamos como encontrar alguns registros neste curso. Afinal, como em geral os trabalhos comparativos nesta extensão tendem a ser uma resposta aos eventos constituintes, modificado após 1918, o cenário geopolítico europeu, muitos impérios foram desconstituídos, e outros tantos Estados emergiram de suas ruínas. Nesta conjuntura, novas Leis Fundamentais foram produzidas e promulgadas, e os pesquisadores, por conta disso, sentiam uma real necessidade de conhecê-las. Assim sendo, marcados pelo caráter estritamente descritivo, e preocupados quase que na sua inteireza por estudar os poderes legislativo e executivo, e suas relações entre si, vale a pena o registro, por exemplo, tanto da obra intitulada "Corso di diritto costituzionale comparato", ${ }^{44}$ da autoria de Antonio Amorth, ${ }^{45}$ quanto

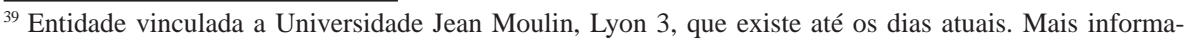
ções podem ser consultadas em seu site: >http://gdc.cnrs.fr/idcel/<.

${ }^{40} \mathrm{O}$ instituto foi descontinuado durante o período da II Guerra Mundial.

${ }^{41}$ Entretanto, como sublinha Leontin Constantinesco (1998, pp. 240-242), apesar de algumas iniciativas, o direito comparado nos países de origem anglo-saxã ainda era decepcionante. Em geral, a qualidade dos trabalhos era medíocre e as orientações muito incoerentes. Algo que, porém, só começa a se modificar antes e durante a Segunda Guerra Mundial, com a chegada, sobretudo, de imigrantes provenientes da Alemanha e do resto da Europa.

${ }^{42}$ Dedicada aos estudos no campo do comércio internacional, a escola foi fundada pelo juiz norteamericano Edwin Parker, e encontra-se atualmente filiada à Universidade de Colúmbia. Mais informações podem ser obtidas em: >http://web.law.columbia.edu/parker-school<.

${ }^{43}$ Instituição que permanece ativa nos dias atuais, e que se dedica a pesquisar comparativamente temas da ordem do dia, tanto no campo privado quanto no público. Para mais informações ver $>$ http:// afla-law.org/<.

${ }^{44}$ Livro publicado em 1936 pela editora Giuffrè.

${ }^{45}$ É importante deixar explícito aqui, de que neste mesmo período, em razão de o ensino do direito público comparado ter se tornado obrigatório nas faculdades de Direito da Itália, é possível que encontremos também alguns trabalhos elaborados por professores nesta direção que, por óbvio, guarda relações diretas com o Direito Constitucional. É o caso, por exemplo, da obra "Corso di diritto pubblico comparato" de Renzo Ravà, e "Appunti di diritto pubblico comparato", de Riccardo Monaco. 
os artigos "A Constituição da Letônia", "A6 Constituição da Tchecoslováquia" e a "A Constituição da Estônia", ${ }^{47}$ escritos respectivamente pelos professores e cientistas políticos, ${ }^{48}$ James Kerr Pollock, Vladimir Dedek e Robert Clark (GINSBURG, 2012, p. 03).

Todavia, apesar destas iniciativas terem conferido grande contribuição ao desenvolvimento do comparativismo, o clima de cooperação internacional que dominou o curto período entre guerras, mais uma vez, ficou prejudicado. Afinal, em um ambiente marcado pelas dificuldades financeiras, políticas e sociais, pelo superveniente crash econômico, e pelo surgimento de diversos governos autoritários, era apenas uma questão de tempo até que estes fatores, unidos, cooperassem para os males que, como se sabe, daí se seguiram. Neste entretempo, "[...] os regimes totalitários dos quais o nacionalsocialismo alemão e o fascismo italiano constituem apenas os exemplos mais marcantes, conduziram o retorno às fontes aborígenes, à rejeição das importações estrangeiras, e à desconfiança em relação às permutas [...]" (ANCEL, 1980, p. 36).

Cessado, no entanto, o lapso de hostilidades do II grande conflito “[...] a esperança de um melhor conhecimento recíproco, preliminar ao entendimento entre os países dilacerados, se eleva das ruínas com um remorso de consciência e um chamamento à razão [...]" (CONSTANTINESCO, 1998, p. 245). Por conta disso, o direito comparado é novamente redescoberto, e os impulsos a seus meandros são revitalizados em outros espaços. Em uma curva vertiginosa e ascendente, crescem com espírito fortificado, tanto as produções científicas quanto as conferências, ${ }^{49}$ e até mesmo a infértil discussão sobre se “[...] o direito comparado continua uma ciência à procura do seu caminho ou um

\footnotetext{
${ }^{46}$ Publicado no ano de 1923 no "The American Political Science Review" no 17.

${ }^{47}$ Ambos publicados no ano de 1921 no "Journal of Comparative Legislation and International Law", no 03 .

${ }^{48}$ De acordo com Martin Shapiro (1993, pp. 365-391), o interesse por cientistas políticos neste campo, no início do século XX, se explica, pois foi nesta etapa que a Ciência Política se constituiu enquanto disciplina nos Estados Unidos. Neste âmbito, estudos constitucionais formavam uma importante parte do núcleo curricular, sendo a pesquisa comparatista, ao menos em parte, um dos aspectos levados em consideração.

${ }^{49}$ A enumeração destes seria extremamente tediosa e, até mesmo, em alguma medida, incompleta, assim sendo, cabe-nos apenas a título meramente ilustrativo, citar aqui, tanto as obras de René David, "Traité Élémentaire de droit civil comparé", de 1950, e a de Felipe de Sola Cañizares, "Tratado de Sociedades por acciones en Derecho Comparado", de 1957, além, é claro, do famigerado Congresso de Paris de 1954, organizado pela Accademia internazionale di diritto comparato.
} 
método que espera uma descrição unívoca [...]" (Op. Cit. p. 246), é retomada. ${ }^{50}$

Em sintonia com este contexto, e a partir da mesma ocasião, a constitucionalização de um conteúdo mínimo de direitos humanos/ fundamentais passa a ser encorajada pela comunidade internacional (FONTANA, 2011, p. 08). Em razão disso, o centro de gravidade dos estudos constitucionais, “[...] que dantes ficava na parte organizacional da Lei Magna - separação de poderes e distribuição de competências, enquanto forma jurídica de neutralidade aparente, típica do constitucionalismo do Estado Liberal - se transporta para a parte substantiva, de fundo e conteúdo [...]" (BONAVIDES, 2004, p. 584). Neste âmbito, as preocupações e questionamentos se sofisticam, e o direito comparado por ser visto como um importante meio de fornecimento de material informativo passa a ser aplicado com mais afinco na particularidade do Direito Constitucional. Todavia, diferentemente do que acontecera no passado, desta vez, a atenção se volta de forma acentuada por parte da academia, motivo pelo qual, este momento é conhecido como, The Rise Era (FONTANA, 2011, p. 18).

No desenrolar deste período, o constitucionalismo comparado acabou caminhando em dois percursos distintos, um de matriz europeia, romanogermânico, e outro de tendência norte-americana. No tocante ao trajeto continental-europeu, a exemplo do que há muito já vinha sendo produzido no domínio do Direito Privado, os estudos se deram através da edição de manuais, preocupados em refletir tanto questões introdutórias, como a terminologia, a função e o método, quanto em apresentar semelhanças e diferenças entre institutos, com base principalmente no exame da doutrina e dos Textos Políticos alienígenas. Neste caso, merecem destaque na Itália, as obras "Corso di diritto costituzionale italiano e comparato", "Lezioni di diritto costituzionale e comparato" e "Introduzione al Diritto costituzionale comparato" da autoria respectiva dos professores Roberto Sandiford, Constantino Mortati, e Paolo Biscaretti di Ruffia. Na Espanha, os livros "Derecho constitucional comparado" de Manuel García-Pelayo, e "Curso de Derecho constitucional

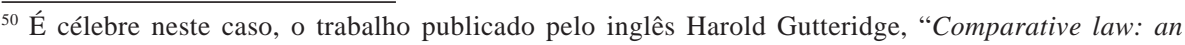
introduction to the comparative method of legal study and research", no qual o autor sustenta "[...] a redução do direito comparado a mero método do saber jurídico, procurando acomodá-lo a tarefas menos ambiciosas, mas mais úteis para os estudos jurídicos, que as que anteriormente lhe tinham sido apontadas [...]" (DUARTE, 2006, pp. 786-787). Além, é claro, na outra ponta, principalmente se procurarmos trazer para o contexto dos estudiosos brasileiros, o artigo intitulado "Direito Comparado, ciência autônoma", publicado em 1952, e da autoria de Caio Mário da Silva Pereira, no qual o jurista defende a cientificidade e a autonomia deste campo.
} 
comparado" de Luis Sanchez Agesta. Na França, o "Cours de droit constitutionnell comparé" de Paul Bastid. E em Portugal o "Notas para uma introdução ao Direito constitucional comparado", de Jorge Miranda (SCARCIGLIA, 2011, p. 56). ${ }^{51}$

Já por seu turno, e do outro lado do Atlântico, em razão de os Estados Unidos terem emergido após a II Guerra Mundial, enquanto uma liderança política e econômica de proporção global, assim como a União Soviética, a realidade deslocou-se em um sentido completamente oposto. Afinal, em tempos de Guerra Fria, preocupavam-se os norte-americanos em dilatar sua zona de influência. Exatamente por isso, como quase tudo o que por lá era produzido à época, também os trabalhos comparatistas acabaram ganhando um firme acento ideológico (ROSENFELD \& SAJÓ, 2012, p. 06). Neste contexto, tanto os estudiosos e pesquisadores, quanto os profissionais do Direito, engajavam-se ativamente no objetivo de verem exportadas as leis e as instituições ianques, sobretudo aos novos países recém-fundados no processo de descolonização (CLARK, 2012, p. 23). ${ }^{52}$ Resultantemente, o constitucionalismo comparado nestas paragens acabou assumindo mais um escopo acadêmico-prático do que crítico-reflexivo. ${ }^{53}$

Com o passar dos anos, porém, arrefecido o calor dos conflitos por independência, mais uma vez o cotejamento na esfera constitucional entrou em declive. É o ciclo conhecido como da Fall Era. ${ }^{54}$ Neste período, por consequência, o interesse, as publicações e os cursos, pouco a pouco foram

${ }^{51}$ Tais bibliografias, compõem aquilo que denominamos de doutrina clássica do constitucionalismo comparado. Isso porque, pouca ou quase nenhuma ênfase davam-se nestes trabalhos ao uso do material comparatista pelas cortes constitucionais.

${ }^{52}$ Refletindo sobre este etapa, David Fontana aponta que (2011, p. 22) "[...] Uma forma de imperialismo cultural e legal pode ser frutuoso para o interesse em torno do Direito Constitucional Comparado, para melhor ou para pior. No caso dos Estados Unidos, tendo em conta o viés normativo dos professores de Direito norte-americanos, quando outros países têm culturas constitucionais semelhantes, explicar tais similitudes se mostra menos interessante do que apontar as diferenças e conferir lições [...]".

${ }^{53}$ Em razão de a revolução dos direitos, ocorrida a partir de 1945, ter ocasionado um deslocamento da supremacia parlamentar para a supremacia judicial, pode-se afirmar que o instituto mais exportado pelos norte-americanos, sem dúvida, foi o judicial review (GARDBAUM, 2013, pp. 02-03). Neste contexto, aliás, vale lembrar que como se estava no período da Corte Warren, uma das mais ativistas da história, responsável, inclusive, pelo julgamento de casos célebres como Brown v. Board of Education, Reynolds v. Sims e Miranda v. Arizona, houve uma contribuição significativa dos próprios justices que compunham o tribunal para que isto se operasse. O próprio Warren viajava frequentemente a inúmeros países para proferir palestras sobre direito constitucional comparado e escrevia um sem-número de ensaios tratando da temática e os publicando nos mais variados tipos de revistas, desde um para a Fortune and Magazine, intitulado "The Law and the Future", até em periódicos de cunho estritamente acadêmico como o American Journal of Comparative Law. (FONTANA, 2011, p.18)

${ }^{54}$ A etapa coincide com o declínio do processo de descolonização, que segundo Antony Best et. al (2008, p. 81), se dá entre o início e o meio da década de 60. 
minguando, até serem praticamente inexistentes. No caso norte-americano, a particularidade fica ainda pelo fato de que o ganho de prestígio obtido pela Supreme Court trouxe igualmente consigo um interesse maior junto aos estudantes e faculdades pela litigação constitucional interna, realidade na qual, por óbvio, não havia espaço para miradas exteriores (FONTANA, 2011, pp. 23-24). Já no que se refere ao continente europeu, à especificidade pode ser traduzida pela carência tanto por novos autores, quanto por novos tópicos a serem abordados, algo que, de igual modo, associado ao fator de política mundial, acabou reproduzindo também por lá, um acentuado decréscimo de impulso na dimensão ora enfocada. ${ }^{55}$

Contudo, a partir do fim dos anos 80, começaram a se configurar mostras de mudança deste cenário (HIRSCHL, 2008, p. 11). Do desmembramento da União Soviética, irrompeu-se outra vez uma onda ${ }^{56}$ constituinte ${ }^{57}$ e, junto dela, aos poucos, o estabelecimento de um judiciário forte e protetor (TATE \& VALLINDER, 1995, p. 02). No entanto, além destes, um outro fenômeno, a globalização, permitirá o constitucionalismo comparado, de agora em diante, se situar em um novo patamar (MICHELMAN, 2000, p. 1063). Afinal, nesta senda, a membrana do Estado-Nação torna-se mais permeável, e a capacidade de governos em impor barreiras à troca de informações, passará a ser continuamente minada pelos avanços no campo da comunicação, do transporte, da tecnologia e em tantos outros (LAW, 2008, p. 1286).

\section{A PERORAÇÃO DE UM VELHO SÉCULO E AS PRIMÍCIAS DE UM NOVO: O RENASCIMENTO DA COMPARAÇÃO CONSTITUCIONAL}

Várias são as acepções possíveis para o termo globalização, conforme sublinha David Law (2008, p. 1278), desde a que identifica que este se refere à escala em que o poder hoje é organizado e exercido, até a que entende que, na

\footnotetext{
${ }^{55}$ A exceção, talvez, da obra de Giuseppe de Vergotini, "Diritto Costituzionale Comparato", cuja publicação se deu em 1981, bem como no Brasil, a de Ricardo Fiuza, "Direito Constitucional Comparado", publicada em 1985, durante vários anos as novidades ficavam apenas por conta da tradução dos manuais já existentes (SCARCIGLIA, 2011, p. 58).

${ }^{56}$ Para Dixon \& Ginsburg (2012, pp. 02-03), a atração pelo ato de comparar está umbilicalmente ligada às denominadas ondas de levantes constitucionais, isto é, aos momentos nos quais se percebe uma proliferação de constituições escritas. Dentre estes períodos que compreendem as revoluções liberais burguesas ou oitocentistas que se sucederam nos séculos XVIII e XIX e o chamado período do pós-guerra, encontra-se de igual modo, o que para os autores trata-se do mais recente deles, o fim da União Soviética, a partir da queda do Muro de Berlim em 1989.

${ }^{57} \mathrm{O}$ que Hirschl (2004, p. 214) denominará de mania de constitucionalismo.
} 
verdade, a expressão reflete um processo contínuo, rápido e de extenso fluxo de bens, serviços, pessoas e ideias. De qualquer sorte, seja qual for a concepção adotada, certo é que as consequências ocasionadas por este evento afetaram e hoje, mais do que nunca, afetam o desenvolvimento do constitucionalismo (LAW, 2008, p. 1279). Isso porque, seus efeitos colaterais tais como a comunicação em tempo real, a política, a economia transnacional e o estreitamento de laços políticos e culturais (HALMAI, 2012, p. 1328) trouxeram como consequência, a prática contemporânea neste campo, um interesse pelo direito comparado pouco experimentado no passado. ${ }^{58}$ Afinal, abriu-se a partir de então, a oportunidade de se ter uma interação maior e mais fácil com fontes, ideias e modelos estrangeiros (HENKIN, 1993, p. 533)..$^{59}$

Não bastasse isso também, a difusão constitucional que se deu nos últimos 30 anos, no qual ou se produziram ou se reformaram o expressivo número de aproximadamente 150 constituições em todo o mundo (HIRSCHL, 2010, p. 771), ocasionando resultantemente uma diversidade de arranjos políticos entre os países, acabou contribuindo, da mesma forma, para o fomento do encanto por esta tendência. Todavia, socorrendo-se aqui do que muito bem aponta Dick Howard (2009, p. 14), "[...] com tantos arranjos constitucionais diferentes a estudar, as oportunidades comparativas mostram-se não apenas muitas, mas sobretudo e principalmente ricas [...]". Basta, aliás, lembrar que, de agora em diante, não se trata de levar em consideração apenas e tão somente o legado anglo-americano ou continental-europeu, mas, na verdade, realizar, em especial, uma abertura a novas realidades, antes dificilmente acessíveis, tal qual as de, por exemplo, Índia, Brasil, África do Sul ou mesmo Taiwan.

Nesta conjuntura, mas não longe de controvérsias, é por isso que os últimos vinte anos vêm sendo caracterizados pela doutrina, como de "ascensão do constitucionalismo mundial" (ACKERMAN, 1996, p. 03), de "globalização do direito constitucional" (TUSHNET, 2009, p. 985), ou ainda, de crescimento do "constitucionalismo transnacional" (JACKSON, 2009, p. 257). E como

\footnotetext{
${ }^{58}$ Neste particular, pode-se citar, inclusive, como uma dos aspectos da globalização que mais chamam a atenção no campo ora estudado, a recentíssima criação pelo site de pesquisa, Google, do Constitute Project, site no qual se abre a oportunidade do internauta ter acesso e comparar as Leis Básicas de todo o mundo. Para mais informações acessar: >www.constituteproject.org<.

${ }^{59}$ Não se quer com isso, porém, dizer que tal interesse não havia no passado, afinal, é o que nos demonstra Jacob Dolinger em trabalho intitulado "The Influence of American Constitutional Law on the Brazilian Legal System". Na referida oportunidade e após fazer um minucioso levantamento de casos, o autor (DOLINGER, 1990, pp. 836-837), chama a atenção para o fato de como os precedentes da Suprema Corte norte-americana influenciaram a jurisprudência do Supremo Tribunal Federal. Desta forma, o que se propõe aqui é enfatizar a existência de um crescimento ostensivo proporcionado pelas facilidades oriundas da globalização.
} 
consequência direta deste intervalo, os Textos Políticos passaram a ter uma dependência crescente de materiais comparativos em todas as fases de seu ciclo de vida (CHOUDHRY, 1999, p. 822). A partir daí, de uma ferramenta importante para se compreender como os Estados se organizam politicamente, ou mesmo para auxiliar na edição de novas Leis Fundamentais, o cotejamento vem se transformando, igualmente, em um destacado e frequente recurso ${ }^{60}$ a ser utilizado por inúmeras cortes constitucionais ao redor do globo, para a solução de casos internos assemelhados (SAUNDERS, 2006, p. 37; SAUNDERS 2012, p. 574$){ }^{61}$

Aliás, é o que deixa claro Hirschl (2008, pp. 12-13), segundo o qual, no mundo contemporâneo, e diferentemente do passado, o direito constitucional comparado é repetidamente utilizado pelos tribunais para fins de autorreflexão, tanto através da analogia, quanto da distinção ou do contraste. Quer dizer, o autor parte do pressuposto de que muito embora diferentes Estados possam enfrentar desafios constitucionais semelhantes, os mesmos podem vir a adotar meios ou abordagens completamente distintos para lidar com tais contendas. Em virtude disso, o ato de juízes em alguns casos fazerem referência à experiência de outros países, presumivelmente em situações análogas, pode se mostrar capaz de enriquecer as práticas constitucionais de um dado sistema político que, inclusive, pode ser aprimorado ao se emularem certos mecanismos desenvolvidos em outras realidades. ${ }^{62}$

À vista disso, muito embora ainda se perceba uma certa reticência por parte de algumas supremas cortes, ao se colocarem muitas vezes em um patamar de defesa da posição tradicional segundo a qual a Lex Magna doméstica deve ser a única fonte levada em conta para a resolução de problemas intestinos

${ }^{60}$ Peter Häberle (2006, p. 66), inclusive, vem pontuando que neste particular, a comparação pode figurar como um quinto método de interpretação, complementando o clássico rol dos quatro apresentados no século XIX por Savigny.

${ }^{61}$ Conforme aludem Rosalind Dixon \& Tom Ginsburg (2012, pp. 03-04) “[...] Com a proeminência crescente dos tribunais constitucionais como locais de tomada de decisão social e política, tornouse evidente que alguns dos problemas enfrentados pelas cortes eram recorrentes entre os países. Muitas das novas democracias, por exemplo, tiveram de lidar com questões de transição, de transformação econômica, bem como de ordem eleitoral, por conta disso, seus tribunais naturalmente começaram a prestar atenção à forma como tais assuntos foram resolvidos em outros países, especialmente nos de democracias já estabelecida e com jurisprudência sobre questões semelhantes bem desenvolvidas $[\ldots] "$.

${ }^{62}$ Afinal, como destaca Jens Dammann (2002, pp. 520-521), a comparação na interpretação constitucional pode tanto ser utilizada para avaliar as possíveis consequências de uma específica e possível interpretação, como determinar a intenção do legislador que se valeu de alguma experiência estrangeira, ou mesmo para descobrir o significado de um termo, ou ainda para corroborar ou contrariar uma interpretação particular. 
(MOON, 2003, p. 229), certo é que, como visto acima, em um arranjo marcado pela disseminação de ideias de um sistema legal nacional em outro, de um sistema legal regional em outro, ou ainda do sistema legal internacional em sistemas legais nacionais (SLAUGHTER, 1994, p. 117), há cada vez menos espaço para doutrinas tais como a das "Quatro Paredes". ${ }^{63}$ Deste modo, tendo em vista que "[...] olhando o direito estrangeiro, podemos muitas vezes enxergar com clareza nossos próprios problemas e desenvolver uma compreensão de possíveis abordagens para os desafios constitucionais mundialmente compartilhados [...]" (JACKSON, 2006, p. 214), figura-se, portanto, resultante o porque de hoje inúmeros magistrados estarem, de fato, se conjugando paradigmaticamente a esta tendência global (MCCRUDDEN, 2000, p. 506), de abertura a importação e a exportação de experiências ádvenas (ROSENFELD, 2001, p. 68). Neste rumo, a memória do passado de uma nação passa a ser gradualmente substituída pelo futuro compartilhado comunitariamente entre os povos (MURKENS, 2008, P. 13).

Diante de tal contexto, e como era de se esperar, já que junto dele, de igual modo, repisam-se e se redirecionam as inquietudes acadêmicas, constatase nos últimos anos, principalmente nos Estados Unidos, ${ }^{64}$ uma migração incidental de pesquisas e estudos, por muitos anos preocupados com a legitimidade do judicial review, para um viés no qual é dada preferência à análise da práxis jurisdicional interpretativa e de sua relação com o uso do referencial estrangeiro (FRANKENBERG, 2012, p. 177). ${ }^{65}$ Tal mudança de atitude, na medida em que tornou possível a investigação em um campo ainda pouco explorado, foi de extrema relevância para o renascimento do constitucionalismo comparado enquanto disciplina (FONTANA, 2011, p. 23).

\footnotetext{
${ }^{63}$ De acordo com os defensores desta doutrina, ventilada pela primeira vez em 1963 na Malásia, no caso Government of State of Kelatan v. Government of Federation of Malaya, sob os esforços do Chief Justice da suprema corte daquele país, Thomson, a constituição deveria ser primariamente interpretada dentro de suas próprias quatro paredes, e não à luz de analogias desenhadas por outros países, como Grã-Bretanha, Estados Unidos ou Austrália. Tal posicionamento, aliás, desde 1994, e a partir do caso Colin Chan v. Public Prosecutor, é considerado como o oficial para o tribunal constitucional malasiano.

${ }^{64}$ Mas não apenas, vale lembrar aqui os esforços também desempenhados principalmente por autores alemães e, em menor escala, por professores naturais da França, Bélgica e Áustria.

${ }^{65}$ De acordo com Paul Kahn (2003, p. 2679), esta orientação "[...] é atualmente dominante na prática contemporânea do constitucionalismo comparado, sendo a principal fonte de interesse no campo [...]". Todavia, não se quer com isso afirmar que o interesse por outras vertentes clássicas, como por exemplo, o cotejamento no âmbito da separação de poderes tenha morrido. Em verdade, o que ocorre aqui é um redirecionamento de esforços, agora mais robustos, para esta linha de investigação.
} 
Neste novel ímpeto, a literatura crescente sobre o assunto, agora inclui tanto monografias e livros publicados pelas principais editoras acadêmicas, ${ }^{66}$ como também a criação de periódicos (HIRSCHL, 2013, p. 02$)^{67}$ dedicados a publicar os mais relevantes trabalhos sobre o tema em tela, caso do International Journal of Constitutional Law. ${ }^{68}$ Da mesma forma, destacam-se ainda o ressurgimento de seminários e cursos na agenda acadêmica de diversas instituições, ${ }^{69}$ e o fato de que as mais importantes escolas de Direito dos Estados Unidos e outras tantas do mundo passaram a considerar a cadeira comparative constitutional law, como essencial no currículo. Um exemplo claro disso, inclusive, é apresentado por Hirschl, ao citar a reforma curricular do primeiro ano do curso de Direito, realizada pela Harvard Law School no ano de 2007. De acordo com o autor (HIRSCHL, 2008, p. 14), nesta, que para ele, aliás, fora a mais significativa modificação dos últimos 100 anos na referida instituição, o objetivo norteador foi justamente o de introduzir os alunos numa visão cosmopolita do Direito e das instituições jurídicas como um todo. E neste particular, por óbvio, é claro que não poderia faltar espaço para o constitucionalismo comparado. ${ }^{70}$

Ocorre que, apesar de todo este dinamismo, não faltou muito para que, embora com novo alento, os intermináveis problemas epistemológicos e metodológicos, agora com outra roupagem, voltassem a assombrar o

${ }^{66}$ Segundo Sujit Choudhry (2006, p. 01), vários foram os trabalhos apresentados nos últimos anos. A título exemplificativo, o autor cita as monografias de Gary Jacobsohn, The Wheel of Law: India's Secularism in Comparative Constitutional Context, de Stephen Tierney, Constitutional Law and National Pluralism, além de outros.

${ }^{67}$ Outros periódicos, porém, apesar de não terem sido criados recentemente, e de nem mesmo terem como linha editorial estudos neste campo, caso da Harvard Law Review, voltaram, após anos sem o fazê-lo, a publicar trabalhos com a temática do constitucionalismo comparado (FONTANA, 2011, p.47).

${ }^{68}$ Periódico publicado desde 2003 pela Oxford University Press em associação com a Faculdade de Direito da Universidade de Nova York, e que se dedica a publicar trabalhos que tenham por objetivo a realização de análises teóricas e práticas, de assuntos que se relacionem com o Direito Internacional e o Direito Constitucional Comparado. Para mais informações ver: http:// icon.oxfordjournals.org/.

${ }^{69}$ Neste particular, vale destacar o seminário "World Constitutionalism" na Yale Law School, oferecido pelo professor Bruce Ackerman, o curso "Selected problems of both constitutional design and adjudication" na Harward Law School, sob a liderança do professor Frank Michelman, o Seminário "Comparative Constitutional Law" na Georgetown Law School, encabeçado pela professora Vicki Jackson, além do curso "Comparative Constitutional Law" na George Washington University's Law School, dirigido pelo professor David Fontana.

${ }^{70}$ É o que, aliás, corrobora Elena Kagan (2008, p. 475), segundo a qual “[...] a mudança teve como firme propósito preparar os estudantes da faculdade para um mundo cada vez mais complexo, e assim, manter a tradição da mesma, de não formar apenas juristas, mas líderes visionários, com capacidade de pensar novos desenhos institucionais, bem como auxiliar na solução de problemas sociais e individuais, desenvolvendo assim a chamada capacidade de imaginação legal [...]". 
constitucionalismo comparado. Afinal, relembradas questões fundamentais alusivas ao próprio significado e propósito das investigações neste campo, digase de passagem, ainda hoje em grande parte subteorizadas, embaçadas e incoerentes (HIRSCHL, 2013, p. 09), ${ }^{71}$ também agora, unida a estas, e o que seria natural de se esperar, vem sendo observado um encaminhamento das preocupações no curso de solucionar indagações tais como, por que, quando e de que forma, tribunais e juízes se utilizam ou deveriam se utilizar de referências alienígenas no contexto constitucional (PERJU, 2012, p. 38). ${ }^{72}$ Neste patamar, aliás, tem se tornado igualmente frequente a crítica de que o uso do constitucionalismo comparado, concentrado quase que na sua inteireza na verificação e no préstimo de disposições legais e decisões judiciais, vem contribuindo apenas para a elaboração de um quadro raso e incompleto da realidade estrangeira da qual pretende se socorrer (HIRSCHL, 2008, p. 35). Contudo, ao contrário do que a princípio possa parecer, não se objetiva com isso desmerecer ou subestimar os trabalhos descritivos de alta qualidade até então produzidos. Pelo contrário. Reconhece-se a importância destes para a compreensão das diversas nuances e sofisticações verificáveis no campo em tela. No entanto, como Leis Fundamentais não se originam, nem muito menos se operam no vácuo (HIRSCHL, 2013, p. 02), vale a colocação de que nos dias presentes, os mesmos já não têm se mostrado mais suficientes. ${ }^{73}$ Motivo pelo qual, é em tal direção que sem dúvida, aqueles instigados a desbravar esta disciplina devem centrar seus esforços.

${ }^{71}$ De acordo com Peer Zumbansen (2012, p. 11) "[...] Assim como no direito comparado, a comparação constitucional em geral, ainda hoje, continua atormentada por um grande grau de incerteza metodológica e teórica [...]".

${ }^{72}$ Como alude Vicki Jackson (2007, p. 161) “[...] Há, é claro, diferentes tipos de debates em diferentes países. Em alguns deles, o debate não é sobre se o direito estrangeiro ou internacional pode ser considerado, mas sim como, quando e com que peso [...]".

${ }^{73}$ Segundo Ran Hirschl (2008, pp. 36-37) "[...] A migração internacional das ideias constitucionais e o interesse acadêmico pelo constitucionalismo comparado atingiram novos máximos. Todavia, a matriz epistemológica e metodológica do campo ainda se encontra turva. A maior parte dos trabalhos produzidos por estudiosos neste campo permanece descritivo, especulativo, normativo e, acima de tudo doutrinário. Muito pouca atenção é dada, por exemplo, a pesquisas empíricas ou mesmo explicativas e conclusivas. Enquanto no início do século XX o confinamento do direito comparado ao conhecimento enciclopédico e às classificações pode ser perdoado, quando visto seu contexto histórico, manter tais abordagens um tanto enigmáticas no começo do século XXI é uma oportunidade perdida. A conversa internacional entre juristas auxiliados por novas tecnologias de informação tem gerado um considerável banco de conhecimento sobre os vários sistemas jurídicos e constitucionais dos países ao redor do mundo. Graças a este rico conjunto de informações, agora é possível, talvez pela primeira vez, se utilizar das pesquisas comparativas para testar hipóteses e formular ideias generalizáveis sobre as relações causais entre as leis e os vários fenômenos políticos, sociais ou econômicos [...]". 


\section{CONSIDERAÇÕES FINAIS}

O presente trabalho teve por objetivo efetuar um resgate histórico do direito constitucional comparado, cobrindo o mesmo desde suas origens mais remotas que vão de encontro aos escritos elaborados por Aristóteles, até o alcance de suas etapas mais recentes. Em tal oportunidade o que se buscou foi dar ênfase tanto as circunstâncias que favoreceram, quanto as que, em certa medida dificultaram o progresso da referida disciplina. A partir daí, embora não se possa afirmar que a citação realizada pelos magistrados a experiências nãonacionais, no processo de fundamentação de suas decisões, seja um fenômeno novo, certo é, que tal recurso no âmbito da jurisdição constitucional, na esteira do que se procurou deixar transparecer, passou a ter uma utilização mais intensa somente com o desenrolar da confluência entre a facilidade de acesso e de troca de informações provocadas pela globalização, a proliferação no fim do século XX e início do século XXI, de novos processos constituintes em vários países, e o estabelecimento neste mesmo período de um judiciário forte e protetor. Esta peculiaridade, como conclusão, situa o direito constitucional comparado em um patamar de questionamentos pouco explorados por aqueles que se dedicavam a estuda-lo no passado, e consequentemente abre espaço para um novo rumo de estudos e pesquisas.

\section{REFERÊNCIAS}

\section{ACKERMAN, Bruce. The rise of world constitutionalism. Occasional} papers, $n^{\circ} 4,1996$. Disponível em:>http://digitalcommons.law.yale.edu/ ylsop_papers/4<. Acesso em 03/01/2013.

ALMEIDA, Carlos Ferreira de; \& CARVALHO, Jorge Morais. Introdução ao direito comparado. Coimbra: Almedina, 2013.

ANCEL, Marc. Utilidade e métodos do Direito Comparado. Porto Alegre: Sérgio Antônio Fabris, 1980.

ARISTÓTELES. Política. Brasília: Editora da UNB, 1985.

BALLIN, Paul Grunebaum. Comment Bonaparte, premier consul, fonda le premier organism français d'étudedes legislations étrangères et du droit compare. In: Revue Internationale de Droti Comparé, 1953. 
BEST, Antony; HANHIMÄKI, Jussi; MAIOLO, Joseph: \& SCHULZE, Kirsten. International History of twentieth century and beyond. New York: Routledge, 2008.

BISCARETTI DI RUFFIA, Paolo. Constituzionalismo. In: Enciclopedia del Diritto. Vol. XI. Milano: Giuffré, 1962.

BITTAR, Eduardo Carlos Bianca. Curso de filosofia aristotélica: leitura e interpretação do pensamento aristotélico. Barueri: Manole, 2003.

BOBBIO, Norberto. Dicionário de Política. Brasília: Editora da UNB, 1997.

BONAVIDES, Paulo. Curso de Direito Constitucional. $15^{\circ}$ Edição. São Paulo: Malheiros, 2004.

CALASSO, Francesco. Storia e sistema delle fonti del diritto comune I: le origini. Milano: Giuffrè, 1938.

CHOUDHRY, Sujit. Globalization in search of justification: toward a theory of comparative constitution interpretation. In: Indiana Law Journal. Vol. 74, 1999.

. Migration as new metaphor in comparative constitutional. In: CHOUDHRY, Sujit. (Org. ). The migration of constitutional ideas. Cambridge: Cambridge University Press, 2006.

CLAES, Monica. Constitutional Law. In: SMITS, Jan M. (Org.). Elgar encyclopedia of comparative law. Cheltenham: Edward Elgar Publishing, 2012.

CLARK, David Scott. History of comparative law and society. In: CLARK, David Scott. (Org.). Comparative Law and society. Edward Elgar Publishing, 2012.

CONSTANTINESCO, Leontin-Jean. Tratado de Direito Comparado: introdução ao direito comparado. Rio de Janeiro: Renovar, 1998. 
COSTA, Rui da Cunha e. Lições de Direito Constitucional Comparado. Coimbra: Editora Livraria Neves, 1915.

DEVEREUX, Daniel. Classical political philosophy: Plato and Aristotle. In: KLOSKO, George. (Org.). The Oxford handbook of the history of political philosophy. Oxford: Oxford University Press, 2011.

DIXON, Rosalind; \& GINSBURG, Tom. Introduction. In: GINSBURG, Tom; \& DIXON, Rosalind. Comparative Constitutional Law. Cheltenham: Edward Elgar Publishing, 2012.

DOLINGER, Jacob. The influence of American constitutional law on the Brazilian legal system. In: The American Journal of Comparative Law. Vol. 38, nº 04, 1990.

DUARTE, Rui Pinto. Uma introdução ao direito comparado. In: O Direito. Ano 138. Vol. IV, 2006.

FONTANA, David. Refined comparativism in constitutional law. In: University of California Law Review. No 49, issue 2, 2001.

. The rise and fall of comparative constitutional law in the postwar era. In: Yale Journal of International Law, vol. 36, 2011.

FRANKENBERG, Günter. Comparative Constitutional Law. In: BUSSANI, Mauro; \& MATTEI, Ugo. (Org.). The Cambridge companion to comparative Law. Cambridge: Cambridge University Press, 2012.

GACTO FERNÁNDEZ, Enrique; MARÍN, José María García; \& ALEJANDRE, Juan Antonio. Manual básico de historia del derecho. Madrid: Laxes, 1997.

GARDBAUM, Stephen. The new commonwealth model of constitutionalism: theory and practice. Cambridge: Cambridge University Press, 2013.

GILISSEN, John. Introdução histórica ao Direito. Lisboa: Fundação Calouste Gulbenkian, 1995. 
GINSBURG, Tom. Introduction. In: GINSBURG, Tom. (Org.).

Comparative Constitutional Design. Cambridge: Cambridge University Press, 2012.

GUTTERIDGE, Harold Cooke. Comparative Law: an introduction to the comparative method of legal study and research. Cambridge: Cambridge University Press, 1949.

HABERLE, Peter. Role and impact of constitutional courts in a comparative perspective. In: PERNICE, Ingolf; KOKOTT, Julianne; \& SAUNDERS, Cheryl. (Orgs.). The future of the european judicial system in comparative perspective. Baden-Baden: Nomos, 2006.

HAHM, David. The mixed constitution in greek thought. In: BALOT, Ryan. (Org.). A companion to greek and roman political thought. Oxford: Wiley-Blackwell, 2009.

HALMAI, Gabor. The use of foreign law in constitutional interpretation. In: ROSENFELD, Michel; \& SAJÓ, András. (Orgs.). The oxford handbook of comparative constitutional law. Oxford: Oxford University Press, 2012.

HARDING, Sarah. Comparative reasoning and judicial review. In: The Yale Journal of International Law. Vol 28, 2003.

HENKIN, Louis. A new birth of constitutionalism: genetic influence and genetic defects. In: Cardozo Law Review. Vol. 14, 1993.

HIRSCHL, Ran. Towards Juristocracy: the origins and consequences of the new constitutionalism. Cambridge: Harvard University Press, 2004.

. The rise of comparative constitutional law: thoughts on substance and method. In: Indian Journal of Constitutional Law. Vol. 02, $\mathrm{n}^{\circ}$ 11,2008 .

The continued renaissance of comparative constitutional law. In: Tulsa Law Review. Vol. 45, nº 10, 2010. 
. From comparative constitutional law to comparative constitutional studies. In: International Journal of Constitutional Law. Vol. $11, n^{\circ} 01,2013$.

HOWARD, A. E. Dick. A traveler from an antique land: the modern renaissance of comparative constitutionalism. In: Virginia Journal of International Law. Vol. 50, issue 1, 2009.

HUG, Walther. The history of comparative law. In: Harvard Law Review. Vol. XLV. 1931.

JACKSON, Vicki. Constitutional law and transnational comparisons: the youngstown decision and american exceptionalism. In: Harvard Journal of Law \& Public Policy. Vol. 30, nº 01, 2006.

. Transnational challenges to constitutional law: convergence, resistance, engagement. In: Federal Law Review. Vol. 35, nº 02, 2007.

. Constitutional engagement in a transnational era. Oxford: Oxford University Press, 2009.

JELLINEK, George. Teoria General del Estado. Buenos Aires: Editorial Albatros, 1958.

JENNINGS, Jeremy. Early nineteenth-century Liberalism. In:

KLOSKO, George. (Org.). The Oxford handbook of the history of political philosophy. Oxford: Oxford University Press, 2011.

KAGAN, Elena. The Harvard Law School revisited: reflecting on Louis D. Brandeis's Harvard Law School reflections. In: The Journal of Law. Vol. $11, n^{\circ} 04,2008$.

KAHN, Paul. Comparative constitutionalism in a new key. In: Michigan Law Review. Vol. 101, 2003.

KLOSKO, George. History of political theory: an introduction. Vol. II. Modern. Oxford: Oxford University Press, 2013.

LAW, David. Globalization and the future of constitutional rights. In: Northwestern University Law Review. Vol. 102, nº 03, 2008. 
LOIS, Cecilia Caballero. Uma Teoria da Constituição: Justiça, Liberdade e Democracia em John Rawls. Tese apresentada ao Programa de PósGraduação em Direito da Universidade Federal de Santa Catarina, como requisito essencial para a obtenção do título de Doutora em Direito, 2001.

MARCOS, Miguel González. Comparative Law at the service of Democracy: a reading of Arosemena's constitutional studies of the Latin American Governments. In: Boston University Law Review, nº 21, 2003.

MARTINEZ, Jenny. Horizontal structuring. In: ROSENFELD, Michel; \& SAJÓ, András. (Orgs.). The Oxford handbook of comparative constitutional law. Oxford: Oxford University Press, 2012.

MCCRUDDEN, Christopher. A common law of human rights?

Transnational judicial conversations on constitutional rights. In: Oxford Journal of Legal Studies. Vol. 20, nº 04, 2000.

MCILWAIN, Charles Howard. Constitutionalism: ancient and modern. Indianapolis: Amagi Liberty Fund, 2007.

MICHELMAN, Frank. W(h)ither the constitution? In: Cardozo Law Review. Vol. 21, 2000.

MONTESQUIEU, Charles de Secondat, Baron de. O Espírito das Leis. São Paulo: Martins Fontes, 1996.

MOON, Cody. Comparative constitutional analysis: should the United States Supreme Court join the dialogue? In: Washington University Journal of Law and Policy. Vol. 12, 2003.

MURKENS, Jo Eric Khushal. Comparative constitutional law in the courts: reflections on the originalists' objections. In: LSE Law, Society and Economics Working Papers. N 15, 2008.

ÖRÜCÜ, Esin. Mixed and Mixing Systems: a conceptual search. In: ÖRÜCÜ, Esin; ATTWOOLL, Elspeth; \& COYLE, Sean. Studies in Legal Systems: mixed and mixing. London: Kluwer Law International, 1996. 
PEGORARO, Lucio; \& RINELLA, Angello. Concepto y método del derecho constitucional comparado. In: GARRIDO, Diego López; GARROTE, Marcos Francisco Massó; \& PEGORARO, Lucio. Nuevo derecho constitucional comparado. Valencia: Tirant lo blanch, 2000.

PERJU, Vlad. Constitutional transplants, borrowing and migrations. In: Boston College Law School Legal Studies Research Paper Series. N ${ }^{\circ}$ $254,2012$.

POSADA, Adolfo. Derecho político comparado. Madrid: Librería General de Victoriano Suárez, 1906.

ROSENFELD, Michel. Constitutional migration and the bounds of comparative analysis. In: New York University Annual Survey of American Law. Vol. 67, 2001.

ROSENFELD, Michel; \& SAJÓ, András. Introduction. In: ROSENFELD, Michel; \& SAJÓ, András. (Orgs.). The Oxford handbook of comparative constitutional law. Oxford: Oxford University Press, 2012.

SARASOLA, Ignacio Fernández. Los partidos políticos en el pensamiento español: de la ilustración a nuestros días. Madrid: Marcial Pons Ediciones de Historia, 2009.

SAUNDERS, Cheryl. The use and misuse of comparative constitutional law. In: Indiana Journal of Global Legal Studies. Vol. 13, 2006.

. Judicial engagement with comparative law. In:

ROSENFELD, Michel; \& SAJÓ, András. (Orgs.). The Oxford handbook of comparative constitutional law. Oxford: Oxford University Press, 2012.

SCARCIGLIA, Roberto. Introducción al derecho constitucional comparado. Madrid: Dykinson S.L, 2011.

SHAPIRO, Martin. Public Law and judicial politics. In: FINIFTER, Ada. (Org.). Political Science: the state of the discipline. Washington DC: American Political Science Association, 1993. 
SLAUGHTER, Anne-Marie. A typology of transjudicial communication. In: University of Richmond Law Review. № 102, 1994.

SMITS, Jan. Comparative law and its influence on national legal systems. In: REIMANN, Mathias; \& ZIMMERMANN, Reinhard. (Orgs.). The Oxford handbook of comparative law. Oxford: Oxford University press, 2006.

TAKII, Kazuhiro. The Meiji Constitution: the Japanese experience of the west and the shaping of the modern state. Tokyo: International House of Japan, 2007.

TATE, Neal; \& VALLINDER, Torbjörn. The global expansion of judicial power. New York: New York University Press, 1995.

TUSHNET, Mark. The inevitable globalization of constitutional law. In: Virginia Journal of International Law. Vol. 49, 2009.

VALLADÃO, Haroldo. O Estudo e o ensino do Direito comparado no Brasil: século XIX e XX. In: Revista de Informação Legislativa. Vol. 08, nº 30, 1971.

ZUMBANSEN, Peer. Transnational comparisons: theory and practice of comparative law as a critique of global governance. In: Osgoode Hall Law School Comparative Research in Law \& Political Economy. № 01, 2012.

ZWEIGERT, Konrad; \& KÖTZ, Hein. Introducción al derecho comparado. Ciudad del México: Oxford University Press, 20.

Artigo recebido em: 10/10/2014 Aprovado para publicação em: 21/11/2014

Como citar: MARQUES, Gabriel Lima. Entre o clássico e o contemporâneo: uma (re)leitura dos fundamentos históricos do Direito Constitucional comparado. Revista do Direito Público. Londrina, v.9, n.3, p.97-128, set./dez.2014. DOI: 10.5433/1980-511X.2014v9n3p97. 